\title{
Trickle Down Efeck dan Perubahan Wajah Masjid di Yogyakarta
}

\author{
Pajar Hatma Indra Jaya \\ Universitas Islam Negeri Sunan Kalijaga \\ pajar.jaya@uin-suka.ac.id
}

\begin{abstract}
In the last ten years, mosques in Yogyakarta are seen to be changing. This article aims at illustrating the changes and explaining the possible causes of the changes. In order to get the answers to such objectives, the researcher randomly searched for mosques in Yogyakarta that had innovative programs. Data showed that Jogokaryan mosque becomes the inspiration for the changes of mosques in Yogyakarta. The development of Jogokaryan mosque has become a "trickle down effect" that affects the revitalization of mosques in Yogyakarta. The concept to always make zero financial balance has raised awareness of the fact that so far infaq has not been spent optimally, while infaq should be used to accommodate the needs of those who make use of mosques. In fact, the spirit of making zero balance has encouraged the creativity of takmir (people involved in mosque management) to provide the best facilities for the worshippers. As a result, mosques in Yogyakarta are becoming more innovative in providing services for worshippers, both related to any services that are directly associated with prayer and related to services for those who are economically poor.
\end{abstract}

Keywords: Changing Face Of Mosque, Trickle Down Effect, Zero Balance

\begin{abstract}
Abstrak
Sepulub tahun terakbir ini masjid-masjid di Yogyakarta menunjukan perubahannya. Artikel ini bertujuan untuk menggambarkan perubahan-perubahan tersebut dan memberikan penjelasan apa yang menjadi penyebab dari perubahan tersebut. Untuk mendapatkan jawaban atas tujuan itu, peneliti secara random menelusuri masjidmasjid di Yogyakarta yang mempunyai program inovatif. Data-data menunjukan bahwa masjid Jogokaryan menjadi inspirasi perubahan masjid di Yogyakarta. Perkembangan masjid Jogokaryan menjadi "trickle down efeck" yang mempengarubi revitalisasi masjid-masjid di Yogjakarta. Konsep mengenolkan saldo menjadipenyadar bahwa selama ini penggunaan infak masjid belum termanfaatkan secara optimal, padahal dana-dana tersebut seharusnya dapat digunakan untuk memfasilitasi kebutuhan para jamaah yang mampir ke masjid. Dengan semangat mengenolkan kas masjid memunculkan kreativitas takmir untuk memberikan fasilitas terbaik yang dibutubkan jamaah. Akibatnya masjid-masjid di Yogyakarta semakin inovatif dalam memberikan layanan bagi jamaah, baik menyangkut layanan yang berbubungan langsung dengan salat ataupun sebagai katup pengaman sosial bagi jamaab yang kurang beruntung secara ekonomi.
\end{abstract}

Kata kunci: Perubahan Wajah Masjid, Trickle Down Efeck, Mengenolkan Saldo

Permalink/DOI: http://dx.doi.org/10.18326/infsl3v12i1.1-24 


\section{Pendahuluan}

Dimana ada umat Islam disitu ada masjid. Pembangunan masjid identik dengan pembangunan Islam karena masjid merupakan identitas Islam. Bagusnya masjid merupakan bagusnya Islam. Berfungsinya masjid merupakan berfungsinya Islam. Runtuhnya masjid juga berarti runtuhnya Islam (Syafi', 2011: 90). Oleh karena itu penting untuk melihat, menganalisis, dan mendorong perkembangan serta perubahan masjid dari waktu ke waktu.

Indonesia termasuk negara dengan jumlah masjid terbanyak di dunia. Raja Salman sampai terkejut ketika mendengar bahwa di Indonesia terdapat 800.000 buah masjid (Ihsanuddin, 04 Maret 2017), meskipun yang tercatat dalam Sistem Informasi Masjid Kementrian Agama baru 228.021 masjid dan 244.109 mushola (http://simas. kemenag.go.id/\#tabs1-js). Di Yogyakarta saja terdapat 7.800 buah masjid. Data jumlah masjid di Yogyakarta tersebut menegaskan bahwa di setiap dusun atau Rukun Warga (RW) terdapat satu masjid atau lebih. Masjid merupakan institusi yang secara geografi dekat dengan masyarakat. Oleh karena itu jika masjid tersebut mampu berdaya dan menjawab kebutuhan masyarakat maka Islam juga akan menampakkan wajah baiknya dalam menyelesaikan masalah masyarakat.

Muhammad Muhib Alwi (2015) menyebut ada lima fungsi masjid. Fungsi pertama masjid sebagai rumah Allah. Dalam fungsi ini masjid diposisikan sebagai tempat ibadah dimana orang menjalankan kewajiban untuk salat (bait Allab). Fungsi kedua masjid sebagai pusat dakwah atau menyampaikan ajaran Islam (bait al-ta'lim). Fungsi yang ketiga adalah masjid sebagai pusat kegiatan sosial, yaitu memposisikan masjid sebagai tempat mengumpulkan harta-infak dari jamaah (bait al-Maal). Fungsi keempat adalah kemampuan masjid untuk memberikan jaminan sosial kepada masyarakat yang membutuhkan (bait al-ta'min), dan fungsi yang kelima masjid dijadikan sebagai bait al-tamwil yaitu dari masjid mampu membiayai usahanya sendiri (Alwi, 2015: 139). Quraish Shihab bahkan merinci ada sepuluh fungsi masjid. Fungsi tersebut adalah masjid sebagai tempat ibadah, masjid sebagai tempat konsultasi dan komunikasi terkait masalah ekonomi sosial kemasyarakatan, tempat pendidikan, 
tempat memberi santunan sosial, basis militer, tempat pengobatan para korban perang, tempat mengadili sengketa, sebagai tempat menerima tamu, tempat menawan tahanan, dan juga sebagai pusat penerangan atau pembelaan agama (Shihab, 1996: 455-456). Namun banyak sekali masjid yang baru difungsikan sekedar sebagai tempat salat saja.

Sepuluh tahun yang lalu, banyak masjid di Yogyakarta yang dibuka hanya ketika salat berjamaah dan ditutup rapat-rapat lagi setelah salat selesai. Masjid selalu dikunci agar terjaga kebersihannya dan tidak kecurian, terutama kehilangan pengeras suara. Namun sepuluh tahun terakhir ini wajah masjid yang seperti itu mulai tergantikan dengan masjid yang memberi banyak layanan ke jamaah. Saat ini banyak masjid di Yogyakarta yang terbuka selama dua puluh empat jam. Bahkan banyak masjid yang menyediakan kebutuhan para jamaahnya secara cuma-cuma, mulai dari air mineral, makan siang setelah sembayang jumat, makan bubur sehabis salat subuh di hari Minggu, bahkan ada masjid yang menyediakan tempat untuk istirahat (rest area). Tulisan ini bertujuan untuk menggambarkan perubahan masjid di Yogyakarta dan memberi penjelasan terkait bagaimana perubahan tersebut bisa terjadi.

Untuk mengetahui perubahan fungsi masjid dan penjelasannya, peneliti menggunakan metode penelitian deskriptif kualitatif guna menyusun kepingan-kepingan cerita dari para informan, data hasil observasi, dan dokumentasi. Peneliti menelusuri beberapa masjid yang peneliti ketahui mengalami perubahan. Ada tujuh masjid yang dijadikan unit analisis dalam penelitian ini, salah satunya masjid yang berada di dekat rumah peneliti, yaitu masjid AlHikmah Sribit, masjid Nurul Yaqin, dan Al-Hidayah Paker di Desa Mulyodadi, Bambanglipuro, Bantul. Dari informasi tersebut peneliti juga melakukan penelusuran masjid-masjid unik yang menyediakan berbagai fasilitas yang belum lama muncul, seperti masjid Nur Amanah yang menyediakan makan siang setelah salat jumat, masjid Al-Munawarroh, masjid Al-Aalim, dan juga masjid Jogokaryan. Datadata yang peneliti peroleh kemudian divalidasi dengan triangulasi sumber dan triangulasi metode. 


\section{Hasil dan Pembahasan}

Trikle Down Efeck dan Perubahan Fungsi Masjid

Semua literatur tentang masjid memberikan deskripsi bahwa masjid di masa Rasulullah tidak hanya difungsikan sebagai tempat ibadah. Selain sebagai tempat beribadah masjid-masjid tersebut juga dijadikan sebagai tempat menyelesaikan segala masalah umat (Syarif, 2015: 116-120; Dalmeri, 2014: 321). Pentingnya masjid juga nampak dari tindakan Rasulullah yang memperioritaskan membangun masjid ketika pertama kali tiba di Medinah. Masjid difungsikan sebagai tempat berkumpul masyarakat. Siapa saja dan kapan saja dapat mengakses bangunan tersebut. Bahkan masjid digunakan untuk tempat tinggal para sahabat ketika belum punya rumah (Supardi: 2001: 6). Namun melihat kenyataan saat ini yangmana masjid hanya difungsikan sebagai tempat salat saja memunculkan gagasan revitalisasi peran masjid di masa sekarang. Hal itu antara lain dengan membuat ide perpustakaan masjid (Zuhdi. 2010: 83) ataupun membuat BMT (Baitul Maal Wat Tamwil) masjid (Alwi, 2015: 150). Namun demikian konsep-konsep tersebut sebagian tidak berjalan dengan baik, apalagi berefek dan mempengaruhi revitalisasi masjid secara lebih luas dalam satu daerah. Kegiatan-kegiatan rekonstruksi fungsi masjid seperti di zaman Rasulullah banyak yang mengalami kegagalan, mengalami "guremisasi", belum berjalan dengan baik, semakin lama semakin kecil dan akhirnya mati (Ajahari, 2009: 71). Namun hal yang berbeda terjadi di Yogyakarta, sepuluh tahun terakhir ini dapat dirasakan adanya masjid-masjid yang mengalami banyak perubahan fungsi.

Masjid Al-Munawaroh dan masjid Nur Amanah merupakan contoh masjid yang nampak semakin maju dan cukup ideal di Kota Yogyakarta. Masjid Al-Munawarroh terletak di Jalan Timoho Baciro Gondokusuman Yogyakarta atau sekitar satu kilometer dari Kampus UIN Sunan Kalijaga. Kedua masjid tersebut memberikan layanan bagi jamaah, baik terkait persoalan layanan langsung atau tidak langsung perihal ibadah.

Masjid Al-Munawaroh mempunyai tempat parkir luas yang mampu menampung sekitar 20 mobil. Memasuki masjid AlMunawarroh jamaah juga dapat mengambil air minum secara gratis 
dari dispenser yang disediakan di bagian depan masjid. Setelah itu jamaah dapat berwudhu dan buang air dengan nyaman. Ukuran kamar mandi masjid Al-Munawaroh cukup luas, sekitar 1,75 meter persegi dengan air yang jernih. Jika membawa tas punggung jamaah dapat menaruhnya terlebih dahulu di loker yang telah disediakan. Memasuki bagian dalam masjid, jamaah akan mendapati udara yang sejuk karena di dinding masjid terdapat dua buah Air Conditioner (AC). Bagi pengunjung yang tidak membawa jam tangan, pada dinding masjid juga tersedia jam dinding dan penunjuk waktu salat. Duduk di dalam masjid cukup nyaman dan hangat karena dilapisi karpet yang cukup tebal. Bagi jamaah yang membawa anak kecil dan takut mengganggu proses salat berjamaah dapat menempatkan diri di bagian samping masjid. Bagi jamaah yang tidak bisa salat berjamaah dengan berdiri, takmir masjid telah menyiapkan kursi di bagian belakang yang dapat diatur posisinya. Setelah selesai salat pengunjung dapat duduk beristirahat di serambi bagian kiri masjid yang telah disediakan. Di tempat istirahat tersebut terdapat taman berisi kolam ikan dan juga tikar serta meja yang bisa digunakan untuk mengetik, baca buku, atau sekedar untuk istirahat sambil menunggu jam masuk kantor kembali. Pengunjung juga dapat membaca buku ataupun Al-Qur'an yang telah disediakan di rak dekat ruang istirahat. Fasilitas yang komplit tersebut menunjukan bahwa terjadi perubahan layanan masjid di Al-Munawaroh.

Agak jauh dari pusat kota Yogyakarta, terdapat masjid Al-Hikmah Sribit dan masjid Al-Hidayah Paker. Dua masjid ini merupakan masjid dengan tipikal masjid di daerah perdesaan. Keduanya terletak di Desa Bambanglipuro, Kabupaten Bantul. Dua masjid tersebut termasuk salah satu masjid yang melakukan beberapa perubahan layanan kepada jamaah dalam lima tahun terakhir. Masjid Al-Hikmah sudah lebih dari tiga tahun setiap Minggu pagi menyediakan makanan (bubur dan jenang) ataupun snack untuk para jamaah salat subuh. Majid Al-Hidayah Paker juga melakukan hal yang sama dan menyediakan galon air minum serta bahan bacaan untuk para jamaah yang ingin singgah dan beristirahat. Pada bulan Ramadhan masjid Al-Hidayah Paker juga menyelenggarakan Kampung Ramadan. Meskipun fasilitas dan kegiatan di dua masjid tersebut belum selengkap masjid Munawaroh, namun adanya 
fasilitas tersebut menunjukan adanya gejala perubahan masjid sampai ke pelosok Bantul.

Menurut informasi salah satu jamaah di masjid Al-Hikmah Sribit, Rony, ia mengatakan bahwa gerakan sarapan bubur bareng terispirasi dari masjid Jogokaryan. Selain itu Mujiyanto, pemuda masjid Al-Hidayah Paker juga mengatakan bahwa Kampung Ramadan Paker juga terinspirasi dari Kampung Ramadan yang berada di Jogokaryan. Mujiyanto mengatakan bahwa informasi tentang kegiatan-kegiatan di Jogokaryan didapat dari surat kabar. Setelah mendapatkan informasi tersebut ide perubahan di bawa ke takmir masjid dan disetujui untuk dilaksanakan.

Dari data di atas menunjukan bahwa ada proses peniruan terkait dengan perubahan fungsi masjid di Yogyakarta. Ada efek rembesan atau trickle down dari keberhasilan masjid Jogokaryan ke masjid-masjid di Yogyakarta. Bahkan peniruan tersebut juga dilakukan beberapa masjid di luar DI Yogyakarta, hal ini nampak dari banyaknya kunjungan ke masjid Jogokaryan. Trickle down efeck sebenarnya teori dan metode pembangunan yang banyak digunakan dalam kajian ekonomi, teori ini menekankan pada keberhasilan satu titik pertumbuhan yangmana dengan munculnya satu keberhasilan pembangunan diharapkan akan memberikan efek berantai berupa rembesan atau rentetan yang mempengaruhi pembangunan masyarakat yang ada di sekitarnya untuk ikut tergerak melakukan peniruan (Jaya, 2012: 69). Keberhasilan pemberdayaan masjid di Jogokaryan menginspirasi, "menular" dan menjadi "bola salju" ke beberapa masjid di Yogyakarta.

Dalam teori pembangunan, perubahan sosial lebih mudah dilakukan dengan cara peniruan (copycate) daripada membuat inovasi baru yang punya resiko kegagalan. Peniruan ini tidak hanya terjadi dalam pengembangan masjid. Keberhasilan konsep pembangunan dengan peniruan atau model tricke down efeck antara lain terjadi dalam pembangunan ekonomi di Singapura (Owyong, 2000: 535). Tulisan Tatang Amirin juga menjelaskan bahwa revitalisasi beberapa Sekolah Dasar (SD) lingkungan Muhammadiyah di Yogyakarta juga terjadi karena keberhasilan satu sekolah yang merembes ke sekolah lain. Keberhasilan SD Muhammadiyah Sapen disebarkan 
ke sekolah-sekolah Muhammadiyah yang lain sehingga sekolahsekolah tersebut terkena pengaruh (imbas) dari keberhasilan SD Muhammadiyah Sapen yang lebih dahulu sukses mengembangkan SD. Bahkan agar peniruan tidak menyimpang dari perencanaan model maka sekolah-sekolah yang lain juga dilakukan pembinaan oleh sekolah yang lebih dulu berhasil. Dalam tulisam Tatang Amirin model pengembangan ini disebut model "Anak Angkat" (Amirin dkk, 2010: 77). Keberhasilan satu sekolah diikuti keberhasilan sekolah lain, demikian keberhasilan pengembangan di suatu masjid akan diikuti dengan peniruan dan perubahan masjid yang lain.

Konsepsi pengembangan masjid dengan cara peniruan sebenarnya bukan sesuatu yang baru di Yogyakarta. Pada awal munculnya, masjid-masjid di Yogyakarta berkiblat pada masjid Gedhe Kauman (Agung/Raya Keraton) Yogyakarta. Ada lima masjid yang kemudian dibangun mengiringi pembangunan masjid Agung Keraton Yogyakarta. Masjid-masjid tersebut dinamakan masjid Pathok Nagoro yang disebar ke lima penjuru mata angin dan masjid Agung sebagai pusatnya. Masjid Pathok Nagoro merupakan versi mini dari konsep masjid keraton sehingga mulai dari segi bangunan atau kegiatannya merupakan cerminan dari kegiatan di masjid Agung (Setyowati, 2017: 11-23).

Dalam kasus masjid Jogokaryan, pada tahun 2016 Kemenag RI mendeklarasikan masjid Jogokaryan sebagai masjid Idarah atau masjid percontohan nasional. Penganugrahan tersebut diberikan karena masjid Jogokaryan mampu melakukan transformasi kampung Jogokaryan dari kampung abangan menjadi kampung santri. Masjid Jogokaryan menjadi "kiblat" bagi pengembangan masjid-masjid di sekitar Yogyakarta.

Salah satu kunci dari proses tersebarnya ide masjid Jogokaryan dalam pengembangan masjid adalah keberhasilan mereka dalam menyelenggarakan Kampung Ramadhan pada tahun 2005. Kampung Ramadan menjadi trigger yang membuka mata masyarakat untuk melakukan perubahan masjid. Inovasi Jogokaryan tidak berhenti di Kampung Ramadan, banyak "kejutan-kejutan" yang membuat kaget dan kagum masyarakat. Tidak terbayangkan kalau sebuah masjid mampu mengumrohkan jamaahnya yang paling rajin ke masjid. 
Tidak terbayangkan sebelumnya kalau sebuah masjid mempunyai hotel di lantai dua masjid, tidak terbayangkan kalau sebuah masjid menyediakan beberapa televisi, mempunyai AC sebagai alat penyejuk udaranya, memiliki CCTV (Closed Circuit Television), website, alat presensi dengan finger print, serta layanan berobat (poliklinik) bagi masyarakat. Bahkan nama masjid Jogokaryan tidak terlalu "lumrah" untuk sebuah masjid di Indonesia karena namanya tidak menggunakan bahasa arab. Salah satu kejutan lainnya, di masjid Jogokaryan terdapat program mengganti sandal jamaah yang hilang ketika berada di masjid. Selama ini masjid identik dengan hilangnya sandal dan sepatu, untuk merubah image tersebut masjid Jogokaryan memberikan jaminan terhadap keamanan sandal dan sepatu para jamaah. Jika ada jamaah yang alas kakinya hilang maka masjid akan menggantinya dengan yang baru. Meskipun masjid Jogokaryan juga mengantisipasinya dengan memberikan layanan penitipan dan alat pemantau CCTV. Namun konsep jaminan bagi sandal jamaah ini merupakan sesuatu yang baru. Inovasi-inovasi yang membuat kejutan ini mampu melancarkan sumbatan kreativitas dan kebekuan dalam pengelolaan masjid dewasa ini.

Beberapa informan mulai terinspirasi dari gerakan masjid di Jogokaryan. Ada beberapa masjid yang meniru perubahan masjid Jogokaryan dengan cara mengundang takmir masjid (Ustad Muhammad Jazir ASP) untuk langsung berbagi pengalaman. Ustad Jazir sendiri bisa dikatakan cukup fenomenal, selain secara fisik beliau berbadan cukup besar, beliau sering sekali menggunakan baju jawa ketika berdakwah. Ada juga masjid yang belajar dengan melakukan kunjungan secara langsung (studi banding). Selain itu ada juga masjid yang menafsirkan sendiri metode revitalisasi masjid Jogokaryan melalui pemberitaan di media massa. Koran dan televisi turut menginspirasi dan mempercepat perubahan.

Selain itu, generasi muda masjid Jogokaryan juga aktif menyebarkan gagasan perubahan masjid melalui website masjid Jogokaryan. Semua materi ceramah-ceramah takmir dan langkahlangkah perubahan masjid dapat diunduh di website masjid. Selain itu masjid Jogokaryan juga mempunyai buletin yang juga diunggah di website mereka. Saat ini generasi muda masjid Jogokaryan juga menyebarkan gagasan perubahan masjid melalui media sosial 
whatsapp. Jadi proses peniruannya tidak seratus persen alamiah, namun ada gerakan-gerakan terorganisir dari anak muda Jogokaryan untuk ikut mempercepat proses desiminasi gagasan revitalisasi masjid ke masyarakat.

\section{Metode Pengembangan Masjid dengan Pengenolan Saldo}

Masjid Jogokaryan merupakan masjid yang sangat fenomenal di era 2000-an. Masjid tidak sekedar difungsikan sebagai tempat ibadah, namun banyak fasilitas masjid disediakan untuk jamaah. Banyaknya kegiatan-kegiatan dan fasilitas untuk jamah ini tidak bisa lepas dari perubahan mindset penggunaan dana infak masjid. Salah satu kata kunci dari banyaknya kegiatan di masjid Jogokaryan adalah kelimpahan dana. Terjadi perubahan kesadaran terkait konsep managemen infak masjid dari menyimpan sebanyak-banyaknya menjadi mengenolkan saldo infak.

Sebenarnya hampir setiap masjid mempunyai simpanan dana yang cukup banyak. Dana-dana tersebut selalu bertambah setiap minggunya karena kotak infak diedarkan setiap salat jumat. Sebagai contoh, dana yang masuk dari infak jumat masjid Al-Munawaroh setiap minggu mencapai Rp2.600.000,00, untuk masjid Al-Hidayah Paker sekitar Rp400.000,00. Selain itu banyak masjid yang juga mendapatkan tambahan dana dari infak di bulan Ramadan. Setiap bulan Ramadan masjid-masjid mendapatkan banyak infak, hal ini tidak bisa lepas pahala yang dilipatgandakan pada bulan tersebut. Dilihat dari sikap menyumbang masyarakat untuk tempat ibadah, masyarakat Indonesia termasuk masyarakat yang religius dan mempunyai semangat memberi (giving) yang tinggi. Hampir tidak ada pembangunan masjid yang macet. Pembangunan masjid Quwwatul Islam sampai membutuhkan dana sekitar 16 milyar, renovasi masjid Jogokaryan tahun 2004 menghabiskan dana kurang lebih 2,1 milyar. Dilihat dari laporan Baznas DI Yogyakarta menunjukan bahwa dana zakat yang masuk setiap bulannya (bulan Desember 2017) mencapai Rp82.289.000,00 dan infak sebesar Rp22.235.281,00.

Selama ini dana infak masjid dikelola secara amanah dan mementingkan kehati-hatian. Hampir setiap masjid jumlah dana yang dimiliki dipampang secara transparan atau diumumkan setiap 
menjelang salat jumat, setiap pengunjung yang datang dapat melihat posisi keuangan masjid. Dana-dana tersebut dikumpulkan selama bertahun-tahun sehingga terkumpul cukup banyak. Di masjid AlHikmah Sribit saat ini mempunyai dana kas sekitar Rp30 juta.

Dana-dana tersebut dikelola oleh takmir dan sebagian besar digunakan untuk membiayai operasional masjid, seperti membayar listrik, kebersihan setiap bulan, pembangunan, dan perbaikan masjid. Meskipun infak digunakan untuk operasional masjid seharihari, namun pemasukan lebih banyak daripada pengeluarannya. Meminjam konsep dalam ilmu ekonomi, setiap tahun masjid-masjid bisa dikatakan untung karena kasnya selalu bertambah. Apalagi di kalangan umat Islam terdapat keyakinan kuat bahwa membantu pembangunan masjid merupakan bagian dari amal jariyah yang tidak putus pahalanya.

Perubahan mindset pengelolaan dana dari menyimpan menjadi menggunakan menjadikan masjid-masjid mempunyai banyak sumber dana untuk kegiatan. Dana infak yang selama ini cenderung hanya digunakan untuk pembangunan fisik masjid, saat ini sudah mulai muncul mindset bahwa dana infak tersebut tidak hanya bisa digunakan untuk pembangunan fisik dan sebisa mungkin dibuat agar saldonya nol rupiah. Langkah ini disamakan dengan menyegerakan penyaluran infak. Dengan saldo nol rupiah maka ada kelimpahan dana untuk kegiatan. Hal ini mendorong para pengurus masjid untuk kreatif dan berkreasi dalam kegiatan memakmurkan masjid.

Konsep mengenolkan kas berasal dari masjid Jogokaryan. Dalam ceramah dan tulisan terkait pengembangan masjid, Ustad Jazir ASP selalu menekankan hal itu. Di Jogokaryan, kesepahaman pola perubah manajemen dana infak masjid terjadi setelah bangunan masjid dirasa cukup bagus secara fisik (renovasi masjid). Dana-dana infak masjid tersebut harus digunakan untuk kegiatan memakmurkan masjid. Bahkan konsepnya, secara ekstrim, pengurus masjid harus berusaha agar dana kas masjid tersebut harus dinolkan (saldo nol). Apalagi berdasar pengalaman, meskipun dana infak selalu digunakan, namun tidak akan pernah habis. Setiap bulan masjid pasti akan mendapat tambahan infak daripara jamaah. Dana infak 
ini sebenarnya sudah cukup untuk membuat layanan bagi para jamaah. Namun di era yang lalu paradigma pengelola takmirnya adalah menggunakan dana umat sehati-hati mungkin sehingga sampai disimpan bertahun-tahun.

Cara berfikir lama yang berusaha mengumpulkan infak sebanyak-banyaknya dan menyimpan dalam waktu lama dapat menimbulkan "sesat berfikir". Simak saja, munculnya Gerakan Mukena Bersih (GMB) pada tahun 2007 yang dimotori oleh Gita Saraswati dan lima temannya ataupun Gerakan Indonesia Minum Gratis. Gerakan tersebut merupakan tamparan bagi pengelola masjid sebab kegiatan-kegiatan tersebut seharusnya tidak membutuhkan bantuan dana dari luar karena setiap minggu hampir setiap masjid mendapatkan dana infak yang cukup dari jamaah. Mukena kotor tidak akan terjadi di satu masjid jika muncul mindset gerakan mengenolkan saldo. Dana yang melimpah tersebut dapat digunakan untuk memberikan layanan yang terbaik bagi jamaah. Hal itu nampak dari kelimpahan infak dan konsep mengenolkan saldo di Jogokaryan yang membuat masjid tersebut punya kegiatan yang hebat.

Jogokaryan tidak fokus pada aktivitas membangun usaha (bait al-tamwi) untuk mengumpulkan uang guna kegiatan masjid. Mereka hanya berusaha mengoptimalkan kegiatan mengumpulkan harta-infak dari jamaah (bait al-maal) dan sponsor dari kegiatan yang mereka gelar. Filosofi mengapa masjid tidak perlu membangun usaha adalah adanya pemikiran ketika masjid membangun usaha dikawatirkkan usaha tersebut juga dilakukan oleh masyarakat. Ketika hal itu terjadi maka kegiatan tersebut hanya akan melukai hati masyarakat karena usaha mereka bersaing dengan usaha masjid. Kalaupun masjid melakukan kegiatan bait al-maal maka dipilih jenis usaha yang tidak dilakukan oleh jamaah, terutama jamaah dari ekonomi lemah sehingga di masjid Jogokaryan memilih usaha hotel dan travel agent.

Salah satu cara untuk membiayai masjid Jogokaryan adalah dengan infak dan mereka membangun terobosan gerakan infak mandiri dengan cara menghitung infak yang harus diberikan setiap jamaah ke masjid. Jamaah yang sudah mampu membayar infak 
sesuai hitungan disebut sebagai jamaah yang sudah mandiri. Dana infak yang harus diberikan ke masjid setiap jamaah dihitung dari jumlah seluruh pengeluaran masjid selama setahun dibagi jumlah pekan dalam setahun dan hasilnya dibagi kapasitas masjid. Di masjid Jogokaryan untuk dapat disebut jamaah mandiri pada tahun 2000-2006 seorang jamaah minimal infak sebanyak Rp1.500,00. Jika lebih dari jumlah tersebut maka disebut jamaah yang membantu, namun jika kurang dari jumlah tersebut maka disebut jamaah yang masih disubsidi (Jazir, 2016).

Beberapa inforan mulai terinspirasi dari gerakan di Jogokaryan. Bahkan kemudian muncul kreativitas yang berbeda dengan yang dilakukan di Jogokaryan. Jadi saldo nol tersebut menginspirasi orang-orang untuk berfikir kreatif, bagaimana untuk melayani jamaah dengan sebaik-baiknya dengan memanfaatkan infak masjid. Gerakan saldo nol tersebut menginspirasi kreativitas. Konsep mengenolkan saldo juga dapat dikatakan merupakan konsep penyampaian amanah secara cepat. Jika infaknya digunakan untuk kegiatan bulan Ramadan maka panitia harus berusaha membuat banyak kegiatan sehingga amanah infak tersebut tersampaikan.

Dalam pelakasanaannya, ada banyak cara dalam mengumpulkan infak dari jamaah. Beberapa masjid masih menggunakan infak yang sama untuk semua kegiatan. Semua uang yang masuk kotak infak dapat digunakan untuk kegiatan setelah dirapatkan dalam rapat takmir. Namun beberapa masjid membuat banyak kotak infak dan rekening (pencatatan) untuk banyak urusan. Di Jogokaryan setiap kotak infak diberi tulisan peruntukannya sehingga pengurus tanpa ragu dapat membelanjakan uang titipan jamaah tersebut. Diantara rekening tersebut ada kotak infak dengan tulisan untuk Infak Subuh (makan bersama habis subuh), kotak infak untuk program "Sego Jumat" (nasi gratis setelah jumatan), Infak Dunia Islam (kegiatan), Infak Parkir, Sedekah Beras Untuk Dhuafa, Infak Operasional. Pemilahan-pemilahan alokasi infak tersebut membuat pengurus lebih mudah mengatur bagaimana cara untuk mengenolkan saldonya.

Konsep mengenolkan saldo juga telah masuk dalam manajemen pengelolaan kegiatan buka puasa (takjilan) di bulan 
Ramadan. Karena uang jamaah yang dikelola panitia harus digunakan sampai habis maka menu takjilan di banyak masjid sangat menggoda. Di beberapa masjid menunya berupa nasi tongseng, nasi padang, rawon, bahkan sate kambing. Saking menariknya menu berbuka puasa di beberapa masjid di Yogyakarta membuat menu tersebut sampai viral di media sosial. Sidik, pengurus masjid Nurul Yaqin menyampikan setelah mendapatkan konsep mengenolkan kas dari Jogokaryan dirinya mulai mempraktikan konsep tersebut untuk pengelolaan dana iuran buka puasa. Oleh karena dananya cukup banyak maka selain menyediakan makanan untuk berbuka, panitia juga menyediakan kurma dan buah-buahan. Prinsipnya uang jamaah yang diniatkan untuk buka puasa harus dihabiskan tanpa saldo untuk kegiatan tersebut.

Di Jogokaryan konsep pengenolan kas, penghitungan infak mandiri, dan juga kegiatan masjid yang semakin rame berkorelasi positif dengan jumlah penerimaan infak di masjid Jogokaryan. Jadi tidak ada ketakutan bahwa gerakan mengenolkan infak membuat jamaah kecewa dan tidak mau berinfak lagi. Bahkan dengan gerakan mengenolkan infak untuk kegiatan membuat jamaah semakin banyak berinfak karena mereka mengetahui bahwa dana infaknya dimanfaatkan dengan baik. Di bawah ini merupakan tabel perkembangan infak di masjid Jogokaryan:

\section{Tabel 1}

\section{Perkembangan jumlah infak masjid Jogokaryan}

\section{Series 1}

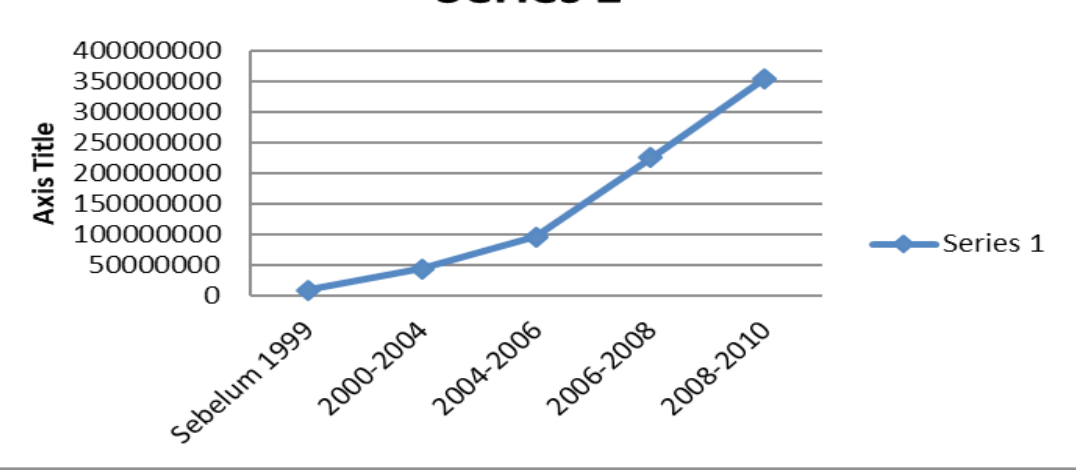

Sumber: Makalah M. Jazir (takmir masjid) 
Tabel di atas menunjukan bahwa capaian infak rata-rata dalam setahun di masjid Jogokaryan menunjukan peningkatan, meskipun menerapkan konsep mengenolkan saldo (kas). Hal itu seharusnya meyakinkan bahwa gerakan mengenolkan infak mendapat respon positif dari para jamaah. Dalam konsep teori pilihan rasional menunjukan bahwa perilaku akan diulang jika pelaku merasa mendapatkan reward yang baik, sebaliknya memberikan infak dalam program tersebut tidak akan diulang jika dianggap merugikan. Muncul pengetahuan bahwa para pemberi infak sebenarnya menginginkan agar infaknya bisa segera digunakan untuk kegiatan keagamaan. Gerakan ini cukup membekas di benak para pengurus masjid di sekitar Yogyakarta, meskipun demikian ada juga yang masih ragu. Meskipun demikian mereka mempunyai ingatan bahwa jamaah ternyata lebih senang jika uang infaknya segera digunakan untuk kegiatan. Inilah yang menginspirasi masjidmasjid di Yogyakarta untuk menyediakan layanan masjid yang lebih baik bagi jamaah.

\section{Bentuk-bentuk Layanan di Masjid sebagai Katup Pengaman Masyarakat}

Membandingkan masjid-masjid di Yogyakarta sebelum tahun 2000 dengan kondisi sekarang nampak jauh berbeda. Muncul layanan-layanan masjid yang sebelumnya tidak ada di masjid pada tahun-tahun sebelumnya. Layanan yang diberikan di masjid ternyata tidak hanya menyangkut persoalan layanan lagsung dalam beribadah, namun juga layanan-layanan dasar yang biasa dibutuhkan masyarakat, seperti penyediaan layanan minuman gratis. Bahkan beberapa masjid juga sengaja membuat kamar mandinya bersih sehingga memudahkan akses siapa saja yang ingin buang air kecil atau BAB (Buang Air Besar). Layanan-layanan sederhana ini dibutuhkan oleh masyarakat. Masjid saat ini mulai terlihat mampu untuk memberikan jaminan sosial atau minimal sebagai katup pengaman untuk menjamin akses masyarakat yang membutuhkan (bait al-ta'min).

Jika dibuat ke dalam tipologi layanan masjid maka ada dua bentuk layanan masjid ke para jamaah. Pertama adalah layananlayanan yang mempunyai kaitan secara langsung dengan ibadah, 
terutama salat. Kedua layanan-layanan yang tidak ada kaitannya secara langsung dengan ibadah salat. Layanan tipe yang pertama ini nampak dari mulai munculnya masjid-masjid ber-AC. Untuk ukuran keluarga di Yogyakarta, AC masih bisa dikatakan barang mewah. Namun jangan heran jika di beberapa masjid di Yogyakarta sudah memasang AC, bahkan di Jogokaryan AC-nya tidak hanya AC dinding, namun juga terdapat AC portabel (Air Cooler). Hal ini berbeda dengan kondisi sepuluh tahun yang lalu, dimana untuk menyejukan udara, masjid masih menggunakan kipas angin. Layanan-layanan ini secara umum membuat jamaah lebih nyaman dalam salat.

Selain itu agar jamaah merasa aman maka di beberapa masjid dipasang loker, baik untuk menyimpan alas kaki atau tas para jamaah. Loker-loker ini menjadi penting karena masjid-masjid di Yogyakarta sering dijadikan tempat salat para mahasiswa yang rata-rata menggunakan tas punggung dan sepatu. Selama ini orang sering kehilangan sandal atau sepatu ketika menjalankan salat berjamaah di masjid. Untuk meningkatkan keamanan di masjid, seperti Jogokaryan ataupun masjid Agung Kota Gedhe telah terpasang kamera CCTV.

Untuk meningkatkan kekhusukan jamaah dalam menunaikan salat di beberapa masjid juga menggunakan karpet-karpet yang empuk. Bahkan terdapat karpet-karpet kualitas hotel. Alas ini juga sudah mengalami perubahan dari masa tahun 90-an dengan menggunakan tikar, beranjak ke tahun 2000-an menggunakan karpet biasa (karpet rumahan), dan saat ini sudah menggunakan karpet tebal, bahkan ada yang menggunakan karpet kualitas hotel berbintang.

Selain layanan-layanan yang punya kaitan langsung dengan salat, masjid juga memberikan layaanan terkait teraksesnya ajaran Islam (bail al-ta'lim). Masjid sebagai tempat belajar Islam sebenarnya sudah muncul sejak dua puluh tahun yang lalu, masjid-masjid di Yogyakarta sudah mempunyai TPA (Taman Pendidikan Al-Qur'an). Dalam perkembangannya beberapa masjid juga telah membangun perpustakaan masjid. Saat ini beberapa masjid sudah mempunyai 
rest area (tempat istirahat) yang juga menyediakan buku bacaan bagi jamaah. Hal ini misalnya nampak di masjid Al-Munawaroh dimana di dalam lingkungan masjid terdapat kolam ikan. Dibuatnya tempat istirahat ini mempunyai dua alasan. Alasan pertama ketika masjid tidak menyediakan tempat khusus maka banyak orang yang istirahat, tidur-tiduran di dalam masjid. Oleh karena hal itu dianggap dapat mengganggu kekhusukan dan kesucian masjid maka perlu difasilitasi. Takmir tidak sekedar melarang orang yang membutuhkan istirahat siang, namun takmir mulai berfikir untuk memfasilitasinya. Hal ini menjadi alasan kedua mengapa masjid menyediakan tempat istirahat. Beberapa masjid berada di lingkungan kantor atau pabrik sehingga karyawan yang masih mempunyai jam istirahat juga membutuhkan suasana yang nyaman. Selain itu ada juga masjid-masjid yang memang dituju oleh para sales yang kantornya jauh untuk yang membutuhkan istirahat. Ada juga para pelintas (musafir) yang sengaja salat sambil mengistirahatkan badan dan kendaraannya.

Para musafir ini tidak hanya membutuhkan ruang untuk istirahat, namun terkadang mereka juga membutuhkan fasilitas lainnya, seperti akses untuk Buang Air Besar (BAB). Di Yogyakarta hampir dipastikan sulit mencari toilet umum milik pemerintah, sehingga orang lebih banyak pergi ke SPBU (Stasiun Pengisisan Bahan bakar Umum) atau di masjid. Di dua lokasi tersebut orang dapat $\mathrm{BAB}$ secara gratis. Namun seiring dengan banyaknya orang yang memanfaatkan BAB di SPBU akhirnya banyak SPBU di Yogyakarta yang mengenakan tarif layanan ketika menggunakan WC. Bahkan di lokasi publik, seperti di pasar Beringharjo untuk kencing saja ditarik uang Rp2.000,00. Muncul perilaku ekonomi semakin banyak yang membutuhkan maka jika dijual akan laku. Pilihan tindakan rasionalitas ekonomi tersebut membuat layanan publik tersebut dikomersialisasikan. Uang Rp2000,00 mungkin dianggap kecil oleh sebagian orang, namun untuk pelajar, mahasiswa, atau kelompok miskin di Yogyakarta, uang Rp2000,00 dapat digunakan untuk membeli sebungkus nasi kucing. Oleh karena itu masjid harusnya menjadi alternatif solusi untuk menjawab kebutuhan tersebut. Masjid merupakan lembaga yang bisa memfasilitasi kebutuhan 
untuk umat. Jika masjid dapat memfasilitasi kebutuhan-kebutuhan layanan tersebut di tengah ideologi mendapatkan keuntungan ekonomi sebanyak-banyaknya maka itulah awal dari kebangkitan masjid untuk layanan umat.

Namun demikian, di awal juga muncul sindiran sinis dari para dai yang menyampaikan bahwa banyak orang ke masjid bukan untuk salat, tapi hanya untuk BAB. Tindakan yang dianggap tidak tepat tersebut membuat pengurus masjid tidak terlalu care dalam menjaga WC-nya. Banyak WC masjid yang dibuat dengan ukuran sangat sempit sehingga orang tidak nyaman dalam menggunakannya. Di beberapa masjid bahkan tidak menyediakan kamar mandi yang ada klosetnya. Bahkan banyak yang tidak disediakan sabun cuci atau lampu kamar mandinya dibiarkan mati. Di banyak masjid saat ini ada cara pandang baru dalam melihat WC masjid. Beberapa WC dibuat cukup lebar dan senyaman mungkin sehingga orang merasa enjoy untuk mampir ke masjid. Memfasilitasi kebutuhan buang air besar atau kecil sebenarnya juga merupakan satu ibadah karena bagian menjaga kesehatan dan anugrah Tuhan. Menggunakan konsep Maslow, BAB dan buang air kecil bisa dikategorikan sebagai kebutuhan fisiologi atau dasar yang harus dipenuhi manusia. Jika manusia sering menahan kencing bisa mengakibatkan penyakit infeksi saluran kencing, pembengkaan kandung kemih, bahkan gagal ginjal dan jika orang terlalu sering menahan $\mathrm{BAB}$ dapat mengakibatkan kanker usus.

Dimana orang harus minum ketika haus dan tidak membawa uang? Di Yogyakarta masa lalu, terutama di daerah pedesaanpedesaan hampir di setiap depan rumah disediakan "kendi" yang berisi air masak untuk diminum oleh siapa saja yang kebetulan lewat dan merasa haus. Namun seiring dengan perubahan biudaya, moda transportasi, dan karakter rumah yang cenderung tertutup dengan pagar tinggi maka kebiasaan seperti itu tidak ada lagi. Padahal air putih sangat dibutuhkan oleh tubuh manusia. Jika kekurangan air tubuh bisa dehidrasi, bahkan bisa mengganggu fungsi ginjal. Ustad Yusuf Mansur, penggagas Gerakan Indonesia Minum Gratis, pernah menderita penyakit yang menghabiskan dana ratusan juta 
yang disinyalir hanya karena kekurangan dalam mengkonsumsi air minum (Ismail, 10 September 2015). Budaya menyediakan air minum sebenarnya bisa dikatakan ajaran Islam karena Rasulullah mengajarkan untuk selalu memuliakan tamu dan musafir (AL-Hasyr 59:9).

Di era-era sebelumnya tidak nampak masjid yang menyediakan air minum, namun saat ini banyak sekali masjid yang menyediakan air mineral dalam galon. Minimal ada masjid Al Munawaroh, masjid Al-Hidayah. Air minum gratis di masjid ini juga merupakan katup pengaman untuk para jamaah yang sedang dahaga, namun kekurangan uang.

Tidak hanya air minum. Saat ini sehabis salat jumat dan sehabis salat subuh banyak masjid yang juga menyediakan makan. Makan untuk umat. Ada pola melebarkan ibadah-ibadah khusus pada waktu-waktu tertentu menjadi dilakukan secara lebih intensif dan luas. Islam menyediakan makan untuk masyarakat, dahulu hal itu hanya dilakukan pada bulan Ramadan saja. Namun nilai-nilai Islam sebenarnya memberikan ajaran untuk peduli kepada orang yang miskin (tidak bisa makan) (Al-Ma'un, 107:3). Sekarang kegiatan tersebut mulai meluas, dari hanya dilakukan pada bulan Ramadan bertambah menjadi hari Jumat dan juga hari Minggu sehabis salat subuh. Bahkan masjid Al-Aalim menyediakan makanan ringan setiap hari untuk para jamaah. Jika gerakan itu mulai dimasifkan lagi, mungkin tidak hanya seminggu dua kali, namun setiap hari, seperti masjid Al-Aalim. Jika ini terjadi maka masjid akan menjadi katup pengaman bagi orang-orang yang sedang kurang beruntung secara ekonomi (kelompok rentan). Hal ini karena ada fakta-fakta yang menunjukan adanya orang yang bunuh diri karena kelaparan. Dengan demikian masjid dapat berfungsi menjadi jaring pengaman sosial (social safety net) ketika ada jamaah yang mengalami guncangan sosial. Guncangan sosial merupakan suatu keadaan tidak stabil yang tiba-tiba akibat situasi krisis, baik yang disebabkan faktor ekonomi, sosial, politik, atau alam.

Namun menariknya, makan di masjid tidak hanya dilakukan oleh orang yang tidak mampu, akan tetapi diperuntukan bagi 
semua jamaah. Bahkan pemberi infak dapat ikut makan bersama. Ini merupakan bentuk dari penerapan semangat kebersamaan (associate). Hal ini perlu dilakukan agar tidak muncul label bahwa makan di masjid itu kurang bergensi karena hanya dikhususkan untuk orang yang tidak mampu. Peruntukan infak lebih luas daripada peruntukan zakat (delapan golongan) sehingga program infak ini dapat terhindar dari kekawatiran terjadinya moral hazard karena penerimanya tidak sesuai.

Program-program layanan di atas nampak dibutuhkan masyarakat, terutama untuk masjid-masjid di wilayah kota. Hal ini karena tipologi kota yangmana banyak masyarakat yang bekerja sebagai buruh yang tidak disediakan makan dari tempatnya bekerja. Selain itu ada juga anak-anak muda yang sedang menuntut ilmu di Yogyakarta. Jika kiriman dari orang tua tidak kunjung datang maka mereka punya referensi harus pergi kemana. Hamam, salah seorang jamaah merasa terbantu dengan program nasi gratis setelah salat jumat di masjid Jogokaryan.

Melihat menunya, kegiatan makan sehabis salat jumat cukup bervariasi. Beberapa masjid ada yang sekedar "gorengan", roti dan air mineral atau teh hangat, namun di beberapa masjid yang lain ada yang menyuguhkan menu yang berganti-ganti, mulai dari nasi kucing, nasi padang, nasi kuning, bahkan ada juga nasi goreng.

Perubahan kondisi masjid di Yogyakarta bisa dikatakan disemangati oleh gerakan mengenolkan kas masjid di Jogokaryan. Layanan-layanan sosial yang didanai dari kas masjid lebih terjaga kesinambungannya daripada yang dicarikan dari donatur secara insidental. Donatur untuk satu program biasanya hanya beberapa orang saja, yang mampu secara ekonomi, sedangkan untuk infak masjid semua orang bisa membantu meskipun jumlahnya kecil. Setiap muslim berlomba-lomba memberikan infak terbaiknya untuk masjid karena mereka percaya bahwa harta yang diinfakan di jalan agama tersebutlah yang akan menjadi penolong mereka di akhirat. Meskipun dalam kacamata Max Weber tindakan tersebut dapat digolongkan sebagai tindakan rasionalitas berbasis nilai. Umat muslim sangat yakin bahwa ada kehidupan setelah kematian yang 
sifatnya kekal. Untuk mendapatkannya maka seorang muslim harus menjalankan kebaikan-kebaikan di dunia, termasuk infak di masjid. Dengan kesadaran tersebut maka masjid tidak akan kekurangan uang meskipun berusaha mengenolkan saldonya.

Saat ini masjid-masjid di Yogyakarta juga menyediakan layanan kursi. Kursi-kursi tersebut cukup membantu jamaah yang kesulitan salat dengan posisi berdiri (difabel). Kursi untuk salat ini muncul setelah berkembangnya paradigma takmir masjid harus bisa melayani "tamu allah" secara baik. Langkah tersebut juga telah muncul di UIN Sunan Kalijaga dan meluas di banyak masjid di sekitar Yogyakarta. Ada proses penyadaran dan peniruan ketika hal itu telah dilakukan di satu masjid dan dirasakan dibutuhkan jamaah.

Dengan berfungsinya masjid untuk memberikan layanan bagi masyarakat akan dapat membatu pemerintah. Layanan tersebut penting sebab meski kondisi perekonomian Indonesia terus membaik, namun Indonesia masih mempunyai 27,77 juta orang miskin yang secara ekonomi serba kekurangan (Badan Pusat Statistik, 2 Januari 2018). Masjid diharapkan dapat menjadi institusi yang bisa menjawab kebutuhan masyarakat.

Jika pengelola masjid dapat melihat kebutuhan umat seharusnya tidak akan terjadi peristiwa orang yang meninggal karena kurang gizi, seperti di Papua. Posisi kurang gizi sebenarnya tidak hanya di Papua, namun di beberapa daerah masih ada yang mengalami kurang gizi. Menurut data Riset Kesehatan Dasar tahun 2013 terdapat 18 provinsi yang memiliki prevalensi gizi buruk-kurang di atas angka prevalensi nasional. Bahkan Jawa Pos memuat berita pada tahun 2017 terdapat 6,5 juta anak Indonesia yang mengalami gizi buruk (Miftahul, 13 Juli 2017; Risdinkes, Balitbang Kemenkes, 2013: 211). Masjid-masjid tidak boleh lagi punya saldo banyak ketika masyarakatnya serba kekurangan. Masjid-masjid tidak boleh hanya berdiri megah, namun angkuh dan tidak peduli dengan kondisi masyarakat sekitarnya. Untuk menjadi ideal maka sebuah lembaga keagamaan, termasuk masjid, harus menjaga tiga semangat, yaitu semangat untuk melayani (service), semangat memberi (giving), dan semangat kebersamaan (associate) (Bahjatulloh, 2016: 486). 


\section{Kesimpulan}

Meskipun semua tulisan tentang fungsi masjid di masa Rasulullah menekankan bahwa masjid tidak hanya digunakan sebagai tempat ibadah saja, namun banyak masjid yang belum bisa menjalankan fungsi yang lain. Hal itu berbeda dengan perkembangan masjid di Yogyakarta, beberapa masjid telah mampu menjadi katup pengaman dalam melayani dan menyelesaikan persoalan masyarakat. Masjidmasjid di Yogyakarta mulai dapat dirasakan kehadirannya.

Trikle down efeck menjelaskan perubahan masjid-masjid di Yogyakarta yang menjadi berkembang pesat karena keberhasilan salah satu masjid. Satu keberhasilan pengelolaan masjid di Jogokaryan memberikan efek multiple kepala masjid-masjid lain untuk melakukan peniruan. Kata kunci dari proses peniruan tersebut adalah filosofi mengenolkan kas masjid. Filosofi tersebut menjadi pengungkit kreativitas para pengelola masjid dalam menggunakan dana infak. Dengan konsep mengenolkan dana kas masjid, takmir masjid berusaha membuat kegiatan yang bermacam-macam, bahkan kegiatan yang tidak ada hubungannya secara langsung dengan salat. Masjid-masjid tidak hanya meniru perkembangan masjid di Jogokaryan, namun mereka juga melakukan modifikasi dan berinisiatif untuk mengadakan kegiatan-kegiatan berdasarkan kebutuhan para jamaah.

Efek peniruan ini berjalan tidak harus melalui belajar secara langsung dengan pengelola masjid Jogokaryan, namun prosesnya seperti bola salju, yaitu menggelinding, peniruan di satu masjid ditiru oleh masjid yang lainnya. Untuk mempercepat proses peniruan dan menjadi gerakan sosial, takmir masjid Jogokaryan turut mendorong proses tersebut melalui penyebaran gagasan lewat website dan media sosial. Jadi meskipun belum pernah ketemu takmirnya atau berkunjung ke Jogokaryan mereka sudah mendapat gambaran dari masjid-masjid yang menirunya atau dari media sosial.

Masjid-masjid di Yogyakarta saaat ini mulai berusaha memfasilitasi kebutuhan jamaah, membuat kenyamanan agar salatnya lebih khusuk dan juga menyediakan fasilitas yang tidak terkait secara langsung dengan kegiatan ibadah salat. Kegiatankegiatan tersebut antara lain berupa memfasilitasi kebutuhan jamaah 
untuk minum, makan, istirahat, dan juga untuk BAB di masjid secara gratis. Layanan tersebut menjadi katup pengaman (social safety net) bagi masyarakat yang kurang beruntung di tengah tekanan ekonomi yang semakin berat ataupun masyarakat yang tiba-tiba mengalami guncangan sosial.

\section{Daftar Pustaka}

Ajahari. 2009. Dimensi-dimensi Pengembangan Fungsi Masjid Di Kota Palangka Raya, Jurnal Studi Agama dan Masyarakat, Vol. 6, No. 1: 61-80.

Alwi, Muhammad Muhib. 2015. Optimalisasi Fungsi Masjid Dalam Pemberdayaan Ekonomi Masyarakat, Al-Tatwir, Vol. 2, No. 1: 133-152.

Amirin, Tatang M., Suyud, Asih, N.M,. 2010. "Model Anak Angkat" Dalam Peningkatan Kualitas Sekolah (Kasus Sekolah Dasar Muhammadiyah Condongcatur Yogyakarta, Jurnal Internasional Manajemen Pendidikan, Vol. 4, No. 2: 74-79.

Badan Pusat Statistik. 2018. Persentase Penduduk Miskin September 2017 Mencapai 10,12 Persen, Berita Resmi Statistik No. 05/01/Th.XXI, 2 Januari 2018.

Bahjatulloh, Qi Mangku. 2016. Pengembangan Pemberdayaan Ekonomi Masyarakat Melalui Kegiatan Filantropi (Studi Kasus Lembaga Tazakka DIII Perbankan Syariah IAIN Salatiga), Inferensi, Jurnal Penelitian Sosial Keagamaan, Vol. 10, No. 2: $473-494$.

Balitbang Kemenkes. 2013. Riset Kesehatan Dasar: Riskesdas 2013. Jakarta: Badan Penelitian Dan Pengembangan Kesehatan Kementerian Kesehatan RI.

Dalmeri. 2014. Revitalisasi Fungsi Masjid Sebagai Pusat Ekonomi Dan Dakwah Multikultural, Walisongo, Vol. 22, No. 2: 321350 . 
Ihsanuddin, 04 Maret 2017, Raja Salman Terkejut Indonesia Punya 800.000 Masjid, Kompas.com; http://nasional.kompas.com/ $\mathrm{read} / 2017 / 03 / 04 / 12144741 /$ raja.salman.terkejut.indonesia. punya.800.000.masjid

Ismail, Rachmadin. 10 September 2015. Hikmab Sakit Yusuf Mansur dan Gerakan Indonesia Minum Gratis, https://news. detik.com/berita/3015009/hikmah-sakit-yusuf-mansur-dangerakan-indonesia-minum-gratis.

Jaya, Pajar Hatma Indra. 2012. Trickle Down Effect: Strategi Alternatif Dalam Pengembangan Masyarakat, WELFARE, Jurnal Ilmu Kesejabteraan Sosial, Vol. 1, No. 1: 69-85.

Jazir, Muhammad. 2016. Menuju Jamaah Mandiri. Makalah diunduh dari http://masjidjogokariyan.com/materi-manajemenmasjid/ tanggal 3 Februari 2018.

Miftahul. 2017. Gizi Buruk Jangkiti 6,5 Juta Anak Indonesia, Jawa Pos 13 Juli 2017, https://www.jawapos.com/ $\mathrm{read} / 2017 / 07 / 13 / 144037 /$ gizi-buruk-jangkiti-65-juta-anakindonesia.

Owyong, David T. 2000. Measuring The Trickle-Down Effect: a Case Study on Singapore, Applied Economics Letters, Vol. 7, No. 8: 535-539.

Setyowati, E., Hardiman, G., Murtini, T.W., dan Surya, V.R.V. 2017. Mengenal Lebih Jauh Masjid Islam Jawa: Dalam Arsitektur Masjid Pathok Negoro, Yogyakarta: Galangpress.

Shihab, Quraish. 1996. Wawasan Al-Quran: Tafsir Maudhu'i atas Pelbagai Persoalan Umat, Bandung: Penerbit Mizan.

Supardi dan Amiruddin, T. 2001. Konsep Manajemen Masjid: Optimalisasi Peran Masjid, Yogyakarta: UII Press.

Syafi, M. 2011. Bangunan Masjid Pada Masa Nabi Dan Implikasinya Terhadap Jamaah Masjid Perempuan. Musawa, Vol. 10, No. 1: 89-106. 
Syarif, Adnan. 2015. Lembaga Pendidikan Islam Klasik (Telaah Atas Fungsi-Fungsi Masjid Pada Periode Klasik), Tarbiyatuna, Vol. 8, No. 1: 109-121.

Zuhdi, Muhammad. 2010. Peran Perpustakaan Masjid Dalam Mencerdaskan Ummat. Al-Maktabah, Vol. 10, No. 1: 83-96. 